\title{
Can Africa Make Use of the New Aid Architecture?
}

\author{
Lennart Wohlgemuth*
}

\begin{abstract}
In 2005, an agreement was reached in Paris between a large number of donor countries and institutions and recipient countries on how to make aid more efficient. This new agreement, called the Paris Declaration, if it is handled rightly, can open up increased ownership of their development agenda for the recipient countries. The agreement is in itself nothing new - it contains ingredients that had been discussed since the 1970s and agreed upon a number of times. The newness is that a number of recipient countries were active in developing the underlying concepts and that there is the opportunity, for those who can take it, of seizing the initiative in the development dialogue. This article argues that the agreement will not lead to automatic improvement but will require the active participation of the host countries.
\end{abstract}

\section{Résumé}

En 2005, un accord a été conclu à Paris entre un grand nombre de pays donateurs, des bailleurs de fonds et des pays bénéficiaires sur la manière de rendre l'aide plus efficace. Ce nouvel accord, appelé la Déclaration de Paris, si elle est correctement mise en œuvre, peut amener les pays bénéficiaires à s'approprier davantage leurs programmes. L'accord en soi n'est pas une nouveauté. Il contient des éléments qui ont fait l'objet de discussions depuis les années 1970 et convenus à plusieurs reprises. La nouveauté est qu'un certain nombre de pays bénéficiaires ont été actifs dans l'élaboration des concepts sous-jacents, et qu'il existe une opportunité, pour ceux qui peuvent en profiter, de saisir l'initiative dans le dialogue sur le développement. Cet article défend que cet accord ne conduira pas à des améliorations automatiques, mais qu'il nécessitera la participation active des pays d'accueil.

* Professor at the Center for African Studies, Gothenburg University, Sweden. 


\section{The Swedish Case}

That this development is far from new will be illustrated by the Swedish discourse during the 1990s. In October 1996, the Swedish government set up a working group in the Ministry for Foreign Affairs with the task of drawing up proposals for 'a new Swedish policy towards Africa'. The expectation was that the report would serve as a basis for a new, more grounded and relevant Swedish Africa policy, which would represent a departure from previous efforts at cooperation.

To elicit ideas and experience from Africa itself, the working group arranged two conferences, attended mainly by African delegates. The first took place in Abidjan, Côte d'Ivoire, in January 1997 under the auspices of the African Development Bank and the Nordic Africa Institute. This dealt with the African development debate in relation to four themes: (1) Africa's democratic culture, including gender equality, security and conflict management; (2) Africa in the international economy; (3) Africa's aid dependency and prospects for changed relations between Africa and other countries; and (4) relations between Sweden and Africa - current situation and future potential (Olukoshi and Wohlgemuth 1998).

Based on the conferences, as well as on substantial and comprehensive consultations among relevant and interested parties in Sweden, the working group published a report in August 1997 (Ministry for Foreign Affairs of Sweden 1997), which in turn was developed into a Government white paper, discussed and approved by Parliament in June 1998 (Ministry for Foreign Affairs of Sweden 1997/98). The result is summarised by the working group as being that the overall objective of Sweden's Africa policy should be 'to support processes of change under African control that involve sustainable improvements in welfare for the majority of citizens and consolidation of their democratic influence'. To that, they added two supplementary objectives closely linked to the main one: 'to strengthen the long-term contacts between Sweden and African nations and societies' and 'to promote a strong African role in the international community' ((Ministry for Foreign Affairs of Sweden 1997).

The objectives as described above contain both a qualitative aspect based on value judgements and a more practical side requiring a number of concrete actions. The first part was deliberated upon in some detail by the then State Secretary of the Ministry for Foreign Affairs, Mats Karlsson, responsible for Development Cooperation, in the following manner:

If Africans are again to become the subjects of their destiny, and not the object of somebody else's design, and if we are ever to approach equality in the still unequal relations between Africa and the world, then it is the capacity of African societies, their governments and people, to analyse, choose and shape that must be strengthened. [...] 
Africa's partners have not yet provided a coherent response on the positive changes unfolding on the continent. [...] This time around, the response cannot come from them alone. This time, the response must intrinsically build on the actions taken and answers given by African societies. More than ever, Africa's friends need to listen and reflect on what is actually said and done in Africa. [...]

Everybody speaks about partnership, but what does it mean? In my view there are both qualitative and methodological aspects to it (Kifle et al. 1997).

Karlsson then lists the aspects he sees as crucial and which later were introduced into the Government bill, as follows:

- A basic attitude relating to sustainability and long-termism. There is need for a real change of attitude. No partnership can thrive or survive without respect for the other.

- Openness and clarity concerning the values and interests that govern cooperation. You cannot engage in a partnership without sharing values.

- An increased element of management by objectives and result orientation of aid, instead of a multitude of predetermined conditions.

- A humble, listening attitude with respect for African assumption of responsibility and awareness of the local environment.

- Clarity of resource commitments, payments and reporting principles.

- Desire for coordination among the donors (Ministry for Foreign Affairs of Sweden 1997/98).

In addition to these qualitative aspects of partnership, the Government Bill also added the following necessary changes to be made to partnership modalities (comments made by the author):

- African leadership and ownership, for example, holding consultative meetings to coordinate donors in the capitals of recipient partners.

- Improved local backing and participation. There must be respect for open political debate, the role of parliament, consultation with private enterprise and civil society.

- Improved coordination. Effective African ownership requires good donor coordination, preferably under the management of the recipient countries.

- Well-developed sectoral and budgetary support, making the number of interactions with donors as small as possible and thereby manageable for the recipient.

- Simplified procedures, minimising the numbers of reporting systems, procurement requirements, payments procedures, accounting routines, etc. 
- Contractual clarity and transparency.

- Increased coherence between different areas of policy. Behind this term are hidden scores of issues with tremendous long-term implications. It is not just the well-known trade and debt issues, but much else that relates to everything from peace and to environment, migration and the many issues that enable economic integration globally.

- Rewards for progress.

- Extraordinary debt-relief inputs for certain countries (Ministry for Foreign Affairs of Sweden 1997/98).

But what does then the new partnership actually lead to in practice? The discussions centred on that question, as did the papers presented and also the final report. The most interesting inputs were made by the African scholars and practitioners participating in the process. They were very clear on their desire and demand for a 'substantial' change in the relationship between the countries in the North and Africa, which concerns major geopolitical questions as well as the behaviour in the day-to-day relationship when it comes to bilateral affairs. The discussion concentrated on the latter and some concrete proposals were made. The major point they made is so self-evident but so difficult to implement in practice, namely, that all agreements between the parties in the North and the South should always be proceeded by a real negotiation where both parties give and take and no one dictates for the other. This is a new but more concrete way of expressing ownership.

After all the discussions and confrontations during the period of the study, it is my very strong opinion that Africans will not expect to be treated in the future as they presently are in their bilateral relationships. Adebayo Olukoshi expresses this succinctly in his syntheses of the presentation made on partnership at the Abidjan conference as follows:

As the 20th century draws to a close, there is a new generation which is emerging out of the ashes of crisis and decline in Africa. It is a self-assured generation that is prepared to engage the world on equal terms. Its faith in the continent is deep-rooted and its determination to make Africa a home of which Africans can be proud is clear. That generation consists of people who are confident of themselves and are driven by a zeal to transform Africa both internally and in terms of its relationship with the rest of the world. It is a generation that is acutely aware of the potentials of Africa and the obstacles within and outside the continent that must be surmounted in order for those potentials to be fully realized. Its goal can be roughly described as entailing a quest for enthronement of developmental democracies in Africa. Under the leadership of this new generation, I envisage a situation where support from 
the international community will be welcome in the task of rebuilding Africa, but not on any terms or at any cost, least of all on conditions drawn up and imposed from outside in a one-sided manner. If need be, this generation is prepared to do it alone and the world should be willing to let it be - if the international community is not prepared to listen to and respect the selfarticulated hopes and aspirations of these Africans, then it should, at least, not obstruct them. In a sense, that was a central message that flowed out of the formal and informal discussions that took place in Abidjan; donors will do well to heed it (Kifle et al., 1997).

After ten years of implementation of this Swedish partnership policy and a continuous discussion worldwide on the issue of ownership and partnership, culminating in the Paris Declaration of 2005, has the situation of domination rather than dialogue really changed? I will here make the point that a possibility for change today really exists; but to make it come true, considerale efforts have to be made on both sides, and in particular that the African governments must take the new opportunity for claiming ownership very seriously and make use of any opportunity to take control of the aid process as it relates to their own country.

\section{The Paris Declaration and Agenda}

During the second High-Level Forum on Aid Effectiveness that was held in Paris in March 2005, following a number of years of discussion and negotiations, development officials and ministers from 91 countries, 26 donors organizations and partner countries, as well as representatives of civil society organizations and the private sector, came together. The problems identified and to be tackled were:

- Lack of local ownership

- Increasing fragmentation, high transaction costs as well as parallel systems, and

- External solutions to problems not adapted to local needs and conditions.

The resulting Paris Declaration has five key features:

- Ownership: This reflects the efforts made by partner countries to exercise effective leadership over their development policies and strategies, and to coordinate development activities. The Declaration commits partner countries to develop and implement their strategies through broad consultative processes, to operationalize these strategies and to take the lead in coordinating development aid in a dialogue with donors, while at the same time encouraging the participation of non- 
state actors. The Declaration calls upon donors to respect this leadership and strengthen the partner countries' capacity to exercise it.

- Harmonization: Efforts by donors that aim at bringing the policies and procedures that govern their support as much into accord as possible, so as to avoid imposing varying and conflicting requirements on partner countries which reduce the effectiveness of the development cooperation efforts. The Declaration emphasizes the need for harmonizing, increasing transparency and improving collective effectiveness (through division of labour) of the donors' actions.

- Alignment: Donors seek to 'align' their support with priorities and strategies set by partner countries, rather than imposing their own priorities. This also means building up and relying on the partner countries’ own mechanisms for implementing projects, rather than putting parallel systems in place. For their own part, partner countries undertake to make a greater effort to adopt sound strategies and set sensible priorities, and to strengthen and improve their institutions.

- Managing for Results: Donors and partner countries jointly undertake to try and manage and implement aid in a way that focuses on the desired results, and to improve evidence-based decision-making. Both parties undertake to work together on a participatory basis to strengthen the capacity of developing countries and to sharpen the focus on result-based management.

- Mutual Accountability: Finally, both donors and partner countries agree to prioritize mutual accountability and transparency in the use of development resources. The Declaration states that this will '(...) also help to strengthen public support for national policies and development assistance'. Mutual progress towards meeting the commitments on aid effectiveness made in the Declaration will be jointly assessed with the aid of country-level mechanisms (Paris High Level Forum 2005).

For the first time ever, the DAC had invited representatives from the recipient community to serious talks on how to make the use of aid more efficient from the viewpoint of the recipients. Some of the countries involved had sent high-level participants to the discussions, thereby taking home the message and seriously trying to implement the new aid architecture and taking charge of the process. Perhaps the most outstanding case is that of Tanzania, where then President Mkapa took a personal interest in the matter and participated in the Paris negotiations. He also took the matters seriously and pressed for an early implementation of the new architecture in Tanzania. It came at a very good time when the relationship between Tanzania and the 
donors was already under scrutiny and reorientation. (The process has been documented in a number of articles and is summarized in Wohlgemuth (2006) and published on the Web [www.africastudies.gu.se]).

\section{The Tanzanian Case}

The development assistance partnership thus came to be placed high on the Tanzanian policy agenda. The government's desire to take control of development assistance became a high priority and some of its best people were appointed to represent Tanzania in the negotiations with the donor community. These efforts were based on the Tanzanian poverty reduction strategy of 2001, which was refined in the second-generation PRS known as MKUKUTA, in 2005. The MKUKUTA strategy was much more home-grown than the first PRS, with donor input being restricted to comments on the draft version.

Based on the MKUKUTA strategy a joint assistance strategy for Tanzania has been developed in 2006, again by the government in consultation with non-state actors, parliamentarians and the donor community. The purpose is to document the progress made thus far in implementing a new aid relationship in Tanzania. It is designed to take the former strategy to a higher degree of national ownership and leadership, and to reduce transaction costs by enhancing harmonization and alignment with national priorities and national systems. Most importantly, the JAST seeks to align each donor's country assistance strategy with the government's long-term outlook and the MKUKUTA, making individual strategies superfluous.

The process has also led to a major shift from project aid to various forms of programme support and budget support. Project aid is thus down from about 1400 projects in the early 1990s to 304 in 2005, which accounted for 45 per cent of total aid in that year; this basket funding also included sector support at 18 per cent and general budget support at 35 per cent (Ministry of Finance Tanzania 2006). The latter, which is the preferred modality by the government, has increased considerably through the present JAST process and drawn an increasing number of donors, including many that have never engaged in this kind of assistance previously. Today eleven bilateral and three multilateral donors are providing general budget support. While the common view has been that recipient countries lose out if the donors gang together, it seems that the opposite is true in Tanzania. An example comes from the cooperation with regard to the general budget support.

This cooperation is based on the presence of a special joint working group, which agrees on a common framework, albeit not without long and complex negotiations. In order to gain the support of so many donors, it was necessary to suggest more than 70 indicators, all of which are reflected in 
the MKUKUTA strategy. This was not acceptable to the government, however, which argued that such a system was far too complex and too difficult to manage. After negotiations, the group finally agreed on 21 indicators.

Another important outcome of the JAST and in the process that led up to its finalization is that donors are requested by the government to cut down on the number of sectors in which they are engaged. This is with the view of minimizing the number of actors in each sector and to make the cooperation more efficient. This is still a work in progress, but as an example the Swedish position is presently that the number of sectors in which to engage is planned to go down from 14 in 2004 to four or five in 2008.

This is just a very short summary of the implementation of the Paris Agenda in Tanzania. It points to some major achievements but also suggests many challenges ahead, both facing the Tanzania Government and citizens of Tanzania as well as the donors. The problems and the international setting are well known, and it is not my intention to minimize the influence that in particular the Bretton Woods institutions still exert on Tanzania as well as on any other country. This is, however, not the topic of this paper.

I will now concentrate on the challenges facing the recipient governments in making use of the opportunities created by the Paris Agenda. Drawing from experiences from other new policies, nothing guarantees that this policy will be high on the agenda in the donor community for long, in particular if progress is not good enough.

\section{Challenges Facing the Public Sector in the Implementation of the Paris Agenda}

Increased ownership, harmonization and alignment plus the emergence of new aid modalities, budget support in particular, will boost the importance of effective institutions and regulations in the recipient country. It is clear that the staff responsible for implementing and coordinating the budget, including external resources, accounting and reporting, must be sufficiently competent to comply with all the new obligations and live up to all expectations. This is an issue that has to be clearly expressed and must exercise all the parties involved in the process. As aid is becoming aligned to the internal system of the host country these rules and regulation concern the citizen of that country as much as, or even more than, the external actors.

Again, taking the Tanzanian Government as an example, it has enacted a number of important new laws and regulations, and a special commission on corruption has presented an agenda for eradicating corruption. One of the most successful developments has been the introduction of a new integrated financial management system for recording and managing spending. This 
system is now being used by all central government spending agencies, as well as by local organizations, and is claimed to be one of the best in operation in Africa today. Other new laws have been passed on public procurement and the budget process. A computerized strategic budget allocation system in line with the MKUKUTA strategy was put in place in 2004-2005. The aid coordination section at the Ministry of Finance is operating well: it has been strengthened and upgraded, and improved aid statistics are being introduced. Statistics regarding aid flows has always been a difficult issue, and Tanzania is presently working on this. Finally, a medium-term pay policy was approved in 2003-2004, paving the way for four ministries to receive selected accelerated salary enhancements (Wohlgemuth 2006).

The donors are also trying to find ways of improving capacity in Tanzania. A number of basket fund programmes to support capacity development in the government sector are currently being implemented. These include a civil service reform programme, a legal sector reform programme and a private sector reform programme. A major problem that still needs to be solved is how technical assistance should be arranged in the new aid architecture. So far, neither the Tanzanian Government nor the donors have come up with a proposal that matches the reforms in other areas. The problem is under discussion, however, and is high on the government's agenda.

Thus, in order to capture the possibilities that follow from the introduction of the Paris Agenda, priority must be given to ongoing capacity development in order to improve accountability and transparency and so as to restrict the opportunities for corruption. However, in order that these developments really will benefit the citizens in the country and not only please the donor community, the underlying policies must be well established in a democratically and participatory climate in the country. The political will to stick firmly to national objectives and priorities presented and approved in democratic elections is thus very essential. The government should furthermore seek to enhance civil society participation in the process in different ways, in particular through the mass media. Parliament also has a crucial role to pay in the implementation of the strategy. Furthermore, considerable thought needs to be given to the way development cooperation is managed (Wangwe, forthcoming).

\section{Conclusions}

International trends and fads come and go. This is particularly true with regard to policies regarding development cooperation. A cynic would stress this fact and see the Paris Declaration as another of these fads, which soon will have left for the next new brilliant idea. It is true in my own experience that the issue of ownership comes back cyclically again and again. But a development optimist would recommend taking advantage of the present fad 
and making the most of it. And many countries, particularly in Asia, have in the past benefited from such a more optimistic, or let us rather say, proactive policy. The world is not going to be a better place than you make it. Imperialistic tendencies will stay on, only the actors might change. It is true, as Adebayo Olukushi states in his assessment of the Blair African Commission, that there is need to make a fundamental reform of the aid system itself. But, as he also states, the time has come for the world to learn to live with an African development train in which Africans are in the driver's seat, fully in charge of the controls (Olukoshi 2006).

It is my sincere contention that the new aid architecture is an opportunity to start the process that he so eloquently asks for. However, further reform of the aid system is no doubt necessary, and the international community must not stop with the Paris Declaration, which after all only relates to the modalities of aid, but go further. I again quote the former Swedish Secretary of Development Cooperation, Mats Karlsson, who concluded the meeting in Abidjan in the following way:

Donor governments may well be serious in accepting much of the above reasoning around partnership, but the real proof of their intent is whether they can handle coherence in their own policies. That is why the issues of global governance, and in particular global economic governance, are crucial. Stronger political dialogue and leadership, better coherence of policies, the adequate and sustained financing of the emerging global public sector's institutions and operations are intrinsically linked to workable partnerships. If these new partnership ideas fail to catch on and fuel virtuous circles, it may well be not just because the Africans are not up to it, as will be presumed by so many in the North, but because the political courage in that very North is lacking.

Ideas of this kind have been advocated by many Africans. They inspired Sweden to reassess its overall Africa policy. That policy was to be based, not on another set of consultancy reports, but on an intense listening exercise with African policy makers, academics and civil society (Kifle et al. 1997).

\section{Note:}

The Paris Declaration on Aid Effectiveness may be consulted online at:http:// www1.worldbank.org/harmonization/Paris/FINALPARISDECLARATION.pdf

\section{References}

Karlsson, M., 1998, For a Genuine Partnership with Emerging Africa, in KayizziMugerwa, S. et al., Towards a New Partnership with Africa: Challenges and Opportunities, Uppsala: The Nordic Africa Institute. 
Kayizzi-Mugerwa, S., Olukoshi, A. O. and Wohlgemuth, L. (eds), 1998, Towards a New Partnership with Africa: Challenges and opportunities, Uppsala: The Nordic Africa Institute.

Kifle, H., Olukoshi, A. O. and Wohlgemuth, L. (eds), 1997, A New Partnership for African Development: Issues and Parameters, Uppsala: The Nordic Africa Institute.

Ministry of Finance, Tanzania, 2006, Practical Experience on How Aid Works in Tanzania, Dar es Salaam.

Ministry for Foreign Affairs of Sweden, 1997, Partnership with Africa: Proposals for a New Swedish Policy Towards Sub-Saharan Africa, Stockholm: Ministry for Foreign Affairs.

Ministry for Foreign Affairs of Sweden, 1997/98, Africa on the Move: Revitalising Swedish Policy Towards Africa for the 21st Century, Stockholm: Government Communication SKR 1997/98 122.

Odén, B. and Tinnes, T., 2003, Tanzania: New Aid Modalities and Donor Harmonisation, Norad Report, 8/2003.

Olukoshi, A., 2006, African Perspectives on the Commission for Africa Report, in Codesria Bulletin 2\&4, 2006

Paris High Level Forum, 2005, Toward Enhanced Aid Effectiveness - High-Level Forum: Harmonisation, Alignment and Results, Paris, 28 February-2 March. [Background note: http://www.adb.org/documents/events/2005/2nd-HighLevel-Forum/media-backgrounder.pdf]

Rogerson, A., 2005, What if Aid Harmonisation and Alignment Occurred Exactly as Intended? A Reality Check on the Paris Forum on Aid Effectiveness, Draft paper for the ODI-Development Centre Workshop on Research Perspectives on Aid Architecture, 4 February.

Wangwe, S., forthcoming, Changing Aid Modalities and Tanzania Development Assistance Partnerships.

Wohlgemuth, L., 2006, Changing Aid Modalities in Tanzania, ECDPM, Policy Management Brief No. 17. 